\title{
Chapter 9 \\ Beyond Risk Factors: Structural Drivers of Violence Affecting Children
}

\author{
M. Catherine Maternowska, Deborah Fry, Alina Potts, and Tabitha Casey
}

\subsection{Introduction}

Over the past 15 years, studies around the globe have conclusively established that physical, sexual and emotional violence affecting children (VAC) is prevalent in all societies and across all income levels at alarming levels (Know Violence in Childhood, 2017; Hillis et al., 2016). Violence is perpetrated in all contexts where children live-in their families, schools, in the care and justice systems, workplaces, neighbourhoods and communities (Hillis et al., 2016; Le, Holton, Romero, \& Fisher, 2016). The outcomes of violence in childhood are well known to have longterm consequences both for individuals and for society (Norman et al., 2012). The research and data have been powerful; discourse among policymakers is shifting from "this does not happen here!" to "what is driving this?" and "how can we address it?"

The Multi-Country Study on the Drivers of Violence Affecting Children ${ }^{1}$ (hereafter, "Drivers Study") set out to answer this question, placing national teams of research practitioners in Italy, Peru, Viet Nam and Zimbabwe at the centre of our process. Increasingly, public health researchers are using a "socio-ecological framework" to understand the interplay of personal, situational and structural factors in condoning

\footnotetext{
${ }^{1}$ See https://www.unicef-irc.org/research/violence-affecting-children/
}

M. C. Maternowska $(\bowtie)$

Global Partnership to End Violence Against Children, Geneva, Switzerland e-mail: catherine.maternowska@end-violence.org

D. Fry $\cdot$ T. Casey

Moray House School of Education, University of Edinburgh, Edinburgh, UK e-mail: debi.fry@ed.ac.uk; Tabitha.Casey@ed.ac.uk

A. Potts

Global Women's Institute, George Washington University, Washington, DC, USA 
or preventing abuse. ${ }^{2}$ Although this framework has gained broad acceptance for conceptualizing violence, there have been few attempts to explore ways in which researchers, practitioners and policymakers can apply the findings from the framework to better understand how individual, community, institutional and structural level risk and protective factors relate to each other and how they influence children's (and women's) vulnerability to, or protection from, violence. The focus of most prevention efforts is too narrowly cast on interpersonal violence and the associated risk factors.

Recent evidence shows that preventing violence is possible, though not necessarily straightforward. To effectively address and ultimately reduce interpersonal violence affecting girls and boys, programmes must be multi-levelled working across ecological contexts. In some cases, macro-level reforms in the criminal justice system and economic development have been linked to violence reduction (Finkelhor \& Jones, 2006). In other cases, evidence of reduced interpersonal violence has been linked to community-level interventions focused on health, economic support and power inequities (Abramsky et al., 2016; Kim et al., 2007). Finally, interventions targeted towards individuals and families in the areas of education, awareness raising and behaviour change have, in some cases, also shown society-wide reductions in violent crime, partner violence and negative parenting practices (Abramsky et al., 2016; Allen, 2011; Jewkes et al., 2008; Knerr, Gardner, \& Cluver, 2011). Only a handful of scholars have looked at the interplay of all these levels and domains to understand patterns of violence and how best to address them. In addition, scholars also often overlook the extraordinary implications of age and its nexus with gender and power: children grow and their capacities and vulnerabilities evolve and change over time. Interventions tend to remain sector-specific-without specificity to age and gender, as if occurring in isolation from the broader structural forces that may be fueling interpersonal violence (Know Violence in Childhood, 2017). Even though promising steps are being taken to better address structural factors (Marcus, 2014; Rumble, Ramly, Nuryana, \& Dunne, 2018), millions of children continue to be exposed and at risk.

The findings from the Drivers Study presented here highlight how these drivers of VAC are contextualized in specific geohistorical places (Christie, 2006). We draw on two drivers of violence common across all four countries-poverty and migration - to illustrate the power of structural factors on children's everyday experiences. We then focus specifically on our findings from Peru to show how these drivers of violence are related to a child's well-being. According to Christie (2011), one of the main challenges for peace psychology is to deepen understanding of the structural and cultural roots of violence promoting the notion of "positive peace" or the ability to promote a society that reduces social, racial, gender, economic and ecological injustices as barriers to peace (Galtung, 1985; Wagner, 1988). Our integrated child-centred framework moves this shared understanding in a common direction.

${ }^{2}$ See, for example: https://www.cdc.gov/violenceprevention/overview/social-ecologicalmodel. html 


\subsection{Methods and the Process}

The Drivers Study utilized an integrated approach to research that relied on existing research: (1) a systematic literature review of peer-reviewed and published academic papers but also including a scoping of existing written material such as research briefs and $\mathrm{PhD}$ theses called "grey literature", which is often difficult to locate through conventional literature searches; (2) an initial mapping of the interventions landscape, particularly of evaluated prevention programmes; and (3) secondary analyses of existing data sets. Analysed together and working in tandem with national teams, each country plotted data against the macro, meso and micro factors of the socioecological model (in relation to children's lives) to yield hypotheses around what might be driving VAC in each country site (Maternowska \& Fry, 2015). Using this approach, we analysed with our national partners nearly 500 published research studies and 10 national data sets addressing VAC across the four country sites.

We fully acknowledge the origins and evolution of the socio-ecological framework for child psychology and violence prevention work. The framework was first conceptualized to explain child development by Bronfenbrenner (1979) and later was used by researchers to elucidate the complex issue of child abuse (Belsky, 1980), sexual coercion (Brown, 1995) and domestic violence (Heise, 1998). By describing an approach for systematically mapping existing qualitative and quantitative data onto it, we offer both a new application for the field of violence prevention for children and a revised version of the framework (Maternowska \& Potts, 2017).

The approach was designed to work alongside national counterparts as coresearchers, rather than passive receptors for policy recommendations. Importantly, it brought together actors from multiple disciplines-including psychologists, economists, historians, medical anthropologists, social workers and specialists in development and urban studies, with each constituency lending its own unique interpretation to the data. National ownership was built into the study design, working directly with government statisticians who conducted secondary analyses incountry rather than exporting the data or outsourcing data analysis to consultants. Data analysts and policymakers alike were provided space to pause, engage and reflect at multiple stages of the process. The human-centred approach favoured relationship-driven research processes that allowed for the time and flexibility that co-creation requires to analyse and synthesize VAC data using a national lens (for more details on the process each country undertook, see: Maternowska et al., 2018).

Figure 9.1 illustrates how patterns of violence are intimately connected to larger institutional and structural factors, referred to as the "drivers" of violence-or forms of harm that create the conditions in which violence occurs. MacNair (2015) explains "structural violence" referring to chronic forms of harm such as poverty, environmental damage, misallocated resources or dangerous working conditions. In all four countries under study, our findings support the idea that no single level within the socioecological model, and no single factor (drivers or risk/protective 

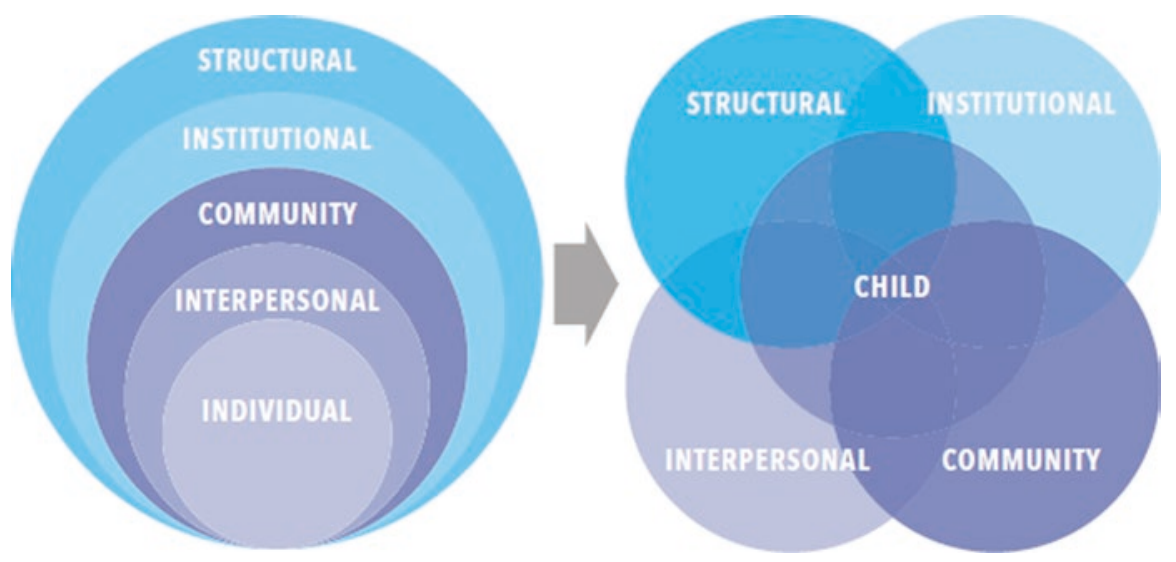

Fig. 9.1 A child-centred socio-ecological framework for violence prevention. (Source: Maternowska \& Potts, 2017)

factors) within or between those levels, determines or explains an act of interpersonal violence involving a child. Instead, these factors work in multiple ways and in multiple combinations where the structural and institutional drivers of violence define and determine the changing context in which children live. The approach adds to a growing body of literature that challenges child protection narratives focused on risk factors, which tend to obscure the social ecology and particularly the determinants of much of the harm that children experience (Featherstone, Gupta, Morris, \& Warner, 2016; Kumar, Sherr, Stern, \& Subrahmanian, 2017; Marcus, 2014).

The integrated framework demonstrates how the structural drivers of violence, such as poverty or gender inequality, are not as distal as interpretations of Bronfenbrenner's evolving socio-ecological model suggest. Importantly, it helps policymakers and practitioners visualize and understand how context shapes children's social worlds. It shifts understandings from a seemingly hierarchical representation of the levels of the socioecological framework to one where the levels - or domains-interact. Bringing this perspective from the field of violence prevention, into the realm of peace psychology, our findings can add to the understanding of both theory and practice for preventing violence and conflict while also mitigating the effects on society. (See, for example, Christie, Wagner, \& Winter, 2001.)

\subsection{Linking the Global and the Local: The Structural Drivers of Violence Affecting Children}

In order to re-conceptualize violence more holistically, making the important links between the global and the local, we review here how poverty and migration can co-conspire, in different ways across different contexts to create unsafe circumstances and vulnerability for some children (and not for others). 


\subsubsection{Poverty}

Across the world, economic transformations-even those designed to address poverty - are often uneven and can generate increasing inequities, with unequal access to wealth and income placing considerable burdens on children. While planned structural transformations can benefit society, leading to better healthcare, increased access to education and a more vital market economy with increased opportunities for earning, they do not fully protect all citizens at all times. Inherent inequalities can reduce government's ability to react to sudden economic shifts, referred to as "shocks" (Bourguignon, 1998; Naschold, 2002). Shocks can substantially rearrange the poorest households' composition and children typically feel the reverberations. Research shows an undeniably complex, and often cyclical, connection between poverty and violence (Parkes, 2015). According to the World Health Organization's World Report on Violence and Health (Krug, Dahlberg, Mercy, Zwi, \& Lozano, 2002), poverty increases one's vulnerabilities to exploitation in the workplace, in schools and in the home. In a review of violence against women, Jewkes (2002) observed that there are few social or demographic characteristics that actually determine risk groups for intimate partner violence, noting, however, that "poverty is the exception" (p. 1423).

Poverty and inequality - which affect children in all countries in this studycreate instability in children's lives, depriving them of basic needs, and this can be linked to increased risks of violence. To develop to their full potential, children need safe and stable housing, adequate nutritious food, access to medical care, secure relationships with adult caregivers, nurturing and responsive parenting and highquality learning opportunities at home and in school. Psychology scholars in South Africa (Seedat, Van Niekerk, Suffla, \& Ratele, 2014), a country struggling with decades of violence, make clear these interconnections. Violence, the authors demonstrate, can trigger significant health, economic, and social consequences where poverty plays a central role. They cite prolonged unemployment, income and gender inequality, exposure to violence in childhood and compromised parenting, in a potent mix with access to firearms, pervasive alcohol misuse and fragilities in law enforcement, as all part of the "tangled social dynamics" of violence.

No country is immune from poverty and its threat of increased exposure to violence. As families feel pressure to cope with changing economic circumstances - in Peru, Viet Nam and Zimbabwe-children may be married early, a situation that predisposes young people to violence (Fry, Hodzi, \& Nhenga, 2016; Guerrero \& Rojas, 2016; Jones, Presler-Marshall, \& Thi Van Anh, 2014). In Italy, Peru and Viet Nam, the poor and extreme poor tend to be concentrated among ethnic minority groups, and inevitably these groups are more vulnerable to violence (Bernacchi \& Zelano, 2016; Vu Manh Loi, 2015). In Italy, the only designated "high-income" country included in the Drivers Study, levels of poverty are increasing: in fact, the number of people living in poverty hit its highest level for a decade in 2015 (Bernacchi \& Zelano, 2016). In cash-strapped and impoverished Zimbabwe, the conditions that create the likelihood for violence include the intersections of poverty, urbanization and housing shortages - all drivers of violence-which directly expose women and girls to violent sexual acts including rape (Dube, 2013). 


\subsubsection{Migration}

The effects of migration, from chronic poverty or low-level conflict, also permeate children's lives in all four countries of the Drivers Study: Italy, Peru, Viet Nam and Zimbabwe. Marginalization and discrimination in new places, challenges to the rights around identity, parents' economic insecurity in new market economies and social and cultural dislocation can all affect children's well-being (Bryant, 2005; Maternowska et al., 2016). Children are affected by migration when they are left behind by one or both migrating parents, migrating with parents (or born abroad) or migrating alone. While the full impact of migration on children and adolescents' development remains under-researched, it is best understood as contributing to forms of violence in childhood when situated within the broader structural context of poverty and/or conflict.

Migration as a driver of violence can have both positive and negative implications depending on its context, including whether migration is voluntary, planned in advance, and whether it is for the purposes of moving the individual and/or family to better circumstances. However, for children in Italy, Peru, Viet Nam and Zimbabwe, migration generally appeared in the literature as a factor linked with instability, due to abrupt changes in individual or family circumstances, or involuntary migration (Government Statistics of Viet Nam, 2012; Magwa \& Ingwani, 2014; Yon Leau, 2013). Rapidly or abruptly changing home environments - with varying, inconsistent and often shifting parental and caretaker support-deny children the stability needed to support positive development. This, coupled with new family constellations and poor integration into new local communities, which may lack consensus around rejecting and sanctioning VAC, can make children more vulnerable to violence (Magwa \& Ingwani, 2014; Strocka, 2008).

In Italy, migration is largely international in scope-while many Italians migrate abroad, more common are the children and adults entering Italy as an escape from conflict and extreme hardship in parts of Africa and the Middle East (Bernacchi \& Zelano, 2016). Among migrants who have crossed the Mediterranean Sea in the last few years, children have been the subjects of attention because a large number of them are unaccompanied minors. From January 1 to November 30, 2017, over 15,500 minors arrived in Italy unaccompanied by an adult responsible; in the previous year, the number was even higher-with over 25,800 minors (Demurtas, Vitiello, Accorinti, Skoda, \& Perillo, 2018).

In Zimbabwe, children, also unaccompanied, frequently move across international borders regionally (within Southern Africa) in search of economic opportunities (Save the Children Norway Zimbabwe, 2010). Factors pushing children from their homes remain understudied, but those identified include poverty and loss of family members due to HIV/AIDS (Chiliya, Masocha, \& Zindiye, 2012; Save the Children, 2008; Save the Children Norway Zimbabwe, 2010). In Peru, Viet Nam and Zimbabwe, the internal migration of children from depressed rural areas to urban slum communities contributes to rapid urbanization and a host of challenges for newly settled families and children (Anderson, 2016; Bray \& Dawes, 2016; 
Rushing, Watts, \& Rushing, 2005). Migration can also be gendered: in Peru and Viet Nam the "feminization" of migration is well documented evidenced by women seeking livelihoods both abroad and within national borders (Anderson, 2016; UNICEF Viet Nam, UNICEF Office of Research - Innocenti, \& University of Edinburgh, 2017).

\subsection{Understanding the Importance of Historical Inequalities to Present-Day Experiences: A Case Study of Peru}

Our findings from Peru, highlighted in a nationally published report (Anderson, 2016), show how structural factors such as poverty and migration, and their linkages with larger structural factors like conflict, are difficult to separate from the everyday violence that children experience. As a middle-income country, Peru has for decades been one of Latin America's most open economies, with Peruvians overall benefitting from economic growth. According to government statistics, less than a third of the Peruvian population now live below the national poverty line, compared with around half in the early 2000s (Anderson, 2016). Nevertheless, about 8 million people remain poor, and poverty is deepest among people of indigenous origin living in remote rural areas. Although more and more Peruvians benefit from economic growth, inequality persists.

An outcome of this rapid inequality has been migration to places outside of Peru as well as from rural areas to cities within Peru (Anderson, 2016). It is estimated that nearly $10 \%$ of Peruvians are affected by international migration. Over $65 \%$ of those migrating to neighbouring countries such as Chile are women (Araujo, Legua, \& Ossandón, 2002), many of whom leave their children in Peru (Illanes, 2010). This "feminization of migration" is largely driven by economic necessity as women search for better livelihoods to support their families (Araujo et al., 2002; Illanes, 2010). Even though the remittances from Peruvians who have moved overseas have enabled many families to improve their standard of living, this does not always equate improved quality of life for children. For example, having one or both parents working in another country is associated with a deterioration in personal relationships (Instituto Nacional de Estadística e Informática \& International Organization for Migration, 2009).

Peru's shifting political economy and the resulting displacement of largely ruralbased Peruvians has affected society as a whole. Anderson (2016) suggests that these internal movements have shifted Peruvian norms away from families and localized, community-oriented systems of protection to those based on individualism and liberal, urban values. Protection provided to children, for example, through extended families no longer functions due to increased geographical (and social) mobility. Changing family constellations under new living conditions places new demands on all household members. Mothers who once enforced norms of nurturing and care may simply not have the time, given new economic demands. The absence of extended families, usually left behind in the migratory process, may 
leave children bereft of the emotional support they once received from the larger family network. The Drivers Study's findings in Peru also show that rapid urbanization has contributed to communities in which diverse groups have, thus far, built little consensus concerning shared norms such as discipline, caretaking responsibilities and children's rights (Anderson, 2016).

Applying the Integrated Child-Centred Framework for Violence Prevention (Maternowska \& Potts, 2017) makes visual the often complex and hard-to-grasp interactions of factors and their effects on children's well-being (see Fig. 9.2).

At the structural level, histories of political violence and rapid economic changes, including over-reliance on extractive industries, have influenced Peruvian policies, which impact on families and children and have also resulted in both rural to urban and international migration.

Extractive industries are a large source of government revenue and encourage foreign investment in mining and the energy sector. Peru's economy remains highly dependent on demand for these extractive metals. In the aftermath of the economic crises of the 1980s and 1990s, the country enjoyed some of the highest levels of growth in Latin America fueled by demand for copper, iron and other raw materials (Anderson, 2016). Ensuring the success of the mining and energy sector subsequently drives policy decisions around housing and community planning in communities around Peru (Anderson, 2016).

Children often migrate with their families to these mining sites in gold-extracting Amazonian basin boom town areas. Several studies highlight how children in these areas are often at high risk of labour and sexual exploitation (End Child Prostitution and Trafficking Peru, 2005; International Organization on Migration \& Movimiento El Pozo, 2005). Rates of child sexual abuse are especially high in mining centres such as Cajamarca (International Programme on the Elimination of Child Labour, 2007; Mujica, 2014).

- Rapid economic transformation

- Histories of Political violence

- Increase in extractive industries

- Age

- Gender

- Race/ethnicity and non-native speakers of Spanish

- Socio-economic status

- Children without ID cards

- Domestic violence

- Parental stress

- Children recruited as assistants in household tasks / caretaking

- Parental absence

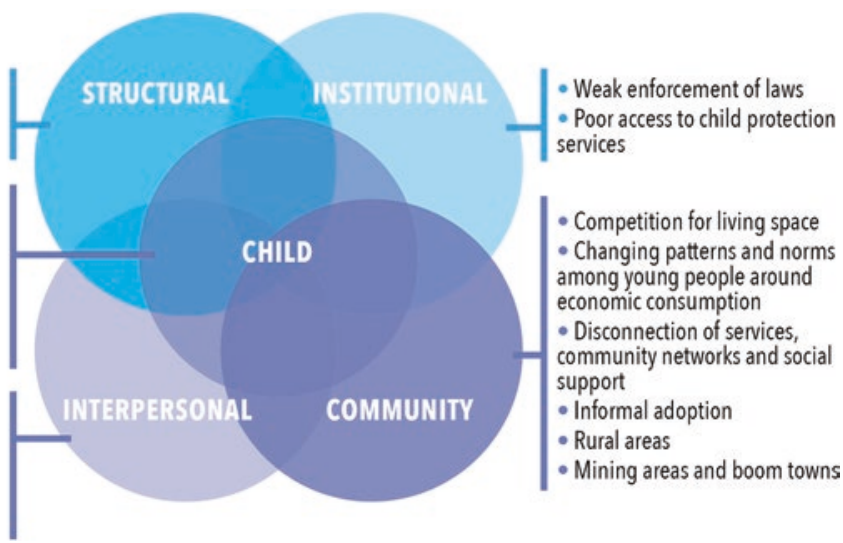

Fig. 9.2 The child-centred socio-ecological framework: exploring the underlying factors related to poverty and migration as a driver of violence affecting children in Peru 
The same economic boom has led nearly $10 \%$ of the population to emigrate out of the country (Anderson, 2016). Remittances from the Peruvian diaspora abroad amount to approximately US\$3 billion or about $10 \%$ of the total value of Peruvian exports (in 2008 dollars, Torres-Zorrilla, 2010, pp. 27-29). The same diaspora has also transmitted new patterns and norms around consumption and living practices. As a result of both international and rural to urban migration, many if not most children were born somewhere other than their parents' or grandparents' birthplaces (Anderson, 2016) resulting in relatively rapid intergenerational understandings of history, place and protection.

At the institutional level, while there is a strong legal framework in place to uphold gender equality, including the criminalization of discrimination against women, these laws and policies are not always effectively implemented, and Peruvian women still experience higher levels of poverty and unemployment than men (OECD, 2010). This may contribute to women's decisions to migrate in search of jobs in other countries or urban areas, with or without their families. Many of the boom towns built around extractive industries have poor law enforcement, another institutional driver of violence, which allows VAC and particularly sexual exploitation to continue with impunity (Mujica, 2014). In addition, child protection services are concentrated in cities and have a very meager presence in the rural, indigenous and frontier areas where some of the poorest families live and work (Anderson \& Palma, 2013).

At the community level, rapid economic transformation leads to changes within households. Household-level poverty can be a risk factor for violence and inevitably interacts with parental stress, larger family sizes and resulting competition for living space juxtaposed against the need to recruit children as assistants in household tasks and caretaking (Nóblega, 2012). With space at a premium, poverty in Peru even influences informal adoptions among families shifting children between households and communities. When children are orphaned, even very poor relatives prefer to take them in rather than send them to orphanages or put them up for formal adoption (Anderson, 2016). Several researchers studying family dynamics have remarked on new forms of kinship where children move (or are moved) to childless couples (Anderson, Minaya, \& Figueroa, 2010; Cavagnoud, 2011; Leinaweaver, 2009). More common cases include receiving a payment or gift for transferring children to households where they will become domestic servants.

Migration has also been linked to families' disconnection from services, community networks and social support (Cuenca \& Díaz, 2010). This is also the case for children who migrate through formal or informal kinship networks to other areas of the country. Sometimes, the protection of the community dissipates when the victimized children are perceived as "other people's children and other people's responsibilities" (Anderson, 2016). This lack of social support is especially pronounced for poorer children who are Afro-Peruvian or mestizo- that is, children of mixed race, especially one having Spanish and American Indian parentage-or from rural origins (CHS Alternativo, 2014; ECPAT Peru, 2005). 
At the interpersonal level, several studies point to the increased parental stress of managing large families under conditions of poverty, which has subsequently been linked as a risk factor for violent discipline, particularly by mothers (Anderson, 2016). This may be because fathers spend less time with children (Guerrero \& Rojas, 2016). It may also be that a father's influence over the quality of family interactions is more indirect, for example, physical punishment may be recognized as violence while failure to provide material support is not (Cavagnoud, 2011; Yon Leau, 2013). In the household, patriarchy serves to promote violence in everyday life (See Espinoza Matos, 2000). Family members identified as "enforcers"- -such as mothers or older brothers - are especially demanding of children and younger siblings as a way of maintaining peace in the family, under patriarchal structures of fatherhood.

It is also important to note the intersections between VAC and violence against women generally and specifically in the case of Peru. Intimate partner violence or "domestic violence", in which the mother is usually the victim, is not only psychologically harmful to children; it is also often associated with physical violence against children by their parents (Bardales \& Huallpa, 2004; Benavides, Almonte, \& de León, 2015; Guedes, Bott, García-Moreno, \& Colombini, 2016). In a study on the context of poverty in Peru, scholars demonstrate how domestic violence contributes to maternal depression, in turn increasing the risk for child neglect (Benavides, León, Veramendi, \& D’Azevedo, 2012). ${ }^{3}$

At the child level, markers of difference between children-such as perceived income levels or race/ethnicity through physical appearance-increase the risk for bullying in schools (INEI, 2013). According to the 2013 National Survey on Social Relations (ENARES by its Spanish acronym), about $70 \%$ of girls and boys reported ever experiencing psychological abuse such as teasing from peers, and about half reported experiencing physical violence from their peers (INEI, 2013). Comparatively, the Young Lives study found that about a third of students at age 15 reported they had been verbally (34\%) or indirectly (32\%) bullied, such as being humiliated or shamed (Pells, Ogando Portela, \& Espinoza, 2016).

Lack of an identification card or "DNI" (Documento Nacional de Identidad), influenced and determined by both poverty and migration status, further increases children's marginalization and vulnerability to violence. Children without a DNI are concentrated in rural areas where not having documentation is strongly associated with the child's mother tongue not being Spanish (Jones \& Villar, 2014).

\footnotetext{
${ }^{3}$ As Guedes et al. (2016) note, "Generally, researchers have paid less attention to poor parenting by men who abuse women, co-occurrence of child maltreatment, or batterers' use of children as weapons against female partners, especially during separation and divorce, despite the fact that using children to threaten and intimidate women has been part of conceptual models for understanding spousal abuse for more than 30 years. In fact, concern for children's safety is a reason why some women stay in abusive relationships and why others leave". [In-text citations removed, see article for studies cited.]
} 


\subsection{Conclusion}

By plotting data across a child's social ecology, the interplay of migration and poverty as drivers of violence becomes clear. The case study from Peru demonstrates this well. Addressing violence first requires thinking about violence with a lens that spans multiple disciplines-drawing on the fields of psychology, economics, political science, history, anthropology and sociology. By plotting the data and making visual these connections, we can begin to unravel the causes and consequences of violence across time and space and ultimately use this information to design or adapt violence prevention interventions and policies. Like peace psychology (Christie, 2006; Pilisuk, 1998; Wessells, 1999), we engaged in multi-level scholarship and practice, attending to the reciprocal links between what happens to children in the home, school and community and how macro-level phenomena, most notably at the structural and institutional levels, intersects, overlaps and interacts with factors at the individual, family and community levels of the socioecological model.

Honouring the role of national policymakers and practitioners in data analysis was enlightening - both for the national stakeholders involved and for the larger sphere of violence prevention studies. In Peru, the process of doing this fostered communication among researchers, practitioners and policymakers working on these issues and facilitated a multi-stakeholder conversation informed by scholars and policymakers from across a range of disciplines. The insights led to documented impacts for those working to prevent violence affecting Peruvian children. Evidenced in Morton and Casey's research impact study (2017), a profound institutional normative change occurred where, over time, the Peruvian government has come to accept both that VAC occurs and, importantly, that the government is empowered and able to take the necessarily steps to prevent it. These efforts are documented in multiple forms, such as support to emerging researchers (including first authorship of peer-reviewed journal articles $)^{4}$, publication of previously unreleased VAC prevalence data by lead government ministries (see MIMP \& UNICEF, 2016), and research-to-policy briefs ${ }^{5}$ documenting these changes.

The Integrated Child-Centred Framework for Violence Prevention (Maternowska $\&$ Potts, 2017) and the approach of the Drivers Study offer insight into processes for generating evidence-informed action to tackle VAC. The framework provides an understanding of structural violence from the perspective of children's lived experiences. Peace psychology as a discipline might benefit from using and adapting frameworks such as these, working alongside other disciplines, such as public health, social work, anthropology and economics. We join Seedat et al. (2014) in suggesting that, as a discipline dedicated to non-violence, it is important for psychology to provide a relevant research response and to promote the transfer of theory to practice, in order to provide a safe world for children everywhere.

\footnotetext{
${ }^{4}$ See https://www.unicef-irc.org/research/pdf/433-Emerging-Researchers-.pdf

${ }^{5}$ See https://www.unicef-irc.org/research/pdf/430-PeruCorpPunENG02.pdf
} 
Violence analysed, from this holistic perspective is important but so too is addressing these inequalities - a challenge for the field of peace psychology as much as the field of violence prevention. Recent evidence-based frameworks, now being promoted within the field of violence prevention such as INSPIRE: Seven Strategies to End Violence, are showing promising results (WHO et al., 2016). Evidence-based strategies from around the world, while still emerging, reinforce the idea that violence can be prevented but must also be simultaneously confronted at different levels, from communities in which children live through to national, regional and global systems (Fulu \& Miedema, 2015). INSPIRE evidence suggests, for example, that the implementation of laws and their enforcement alone cannot be effective without simultaneous attention to safe environments, education and life skills and income generation, to name only some of the seven effective violence prevention interventions outlined (WHO et al., 2016).

The dual perspectives of peace psychology, with its emphasis on movement towards more socially just structures, and violence prevention would benefit from closer alliance to each other. No matter the discipline, the fact is that peace is a precarious notion for children growing up in this rapidly changing world. As much of the world continues to experience crises and shocks due to conflict, forced displacement, economic migration, climate disasters and disease outbreaks, it is incumbent upon us to bring our perspectives - and our applied practice- together to prevent and ultimately end violence affecting children.

\section{References}

Abramsky, T., Devries, K. M., Michau, L., Nakuti, J., Musuya, T., Kiss, L., ... Watts, C. (2016). Ecological pathways to prevention: How does the SASA! Community mobilisation model work to prevent physical intimate partner violence against women? BioMed Central Public Health, 16(1), 339.

Allen, G. (2011). Early intervention: The next steps, an independent report to Her Majesty's government by Graham Allen MP. London, UK: The Stationery Office.

Anderson, J. (2016). Multi-country study on the drivers of violence affecting children: Peru report. Lima, Peru: MIMP \& UNICEF.

Anderson, J., Minaya, L., \& Figueroa, B. (2010). Trabajo infantil doméstico. Percepciones de niñas, niños y adolescentes. Lima, Peru: Asociación Grupo de Trabajo Redes.

Anderson, J., \& Palma, H. (2013). Los ciudadanos menores del Perú. In M. Z. Lobato \& S. Venturoli (Eds.), Formas de ciudadanía en América Latina (pp. 105-125). Madrid, Spain: Iberoamericana.

Araujo, K., Legua, M. C., \& Ossandón, L. (2002). Migrantes andinas en Chile. El case de la migración peruana. Santiago, Chile: Fundación Instituto de la Mujer.

Bardales, O. M., \& Huallpa, E. A. (2004). Aprender sin miedo. Lima, Peru: Ministerio de la Mujer y Desarrollo Social, Gobierno del Perú.

Belsky, J. (1980). Child maltreatment: An ecological integration. American Psychologist, 35(4), 320.

Benavides, M., Almonte, J. L. J., \& de León, M. P. (2015). The co-occurrence of domestic and child violence in urban Peru: Evidence from three regions. Journal of Family Violence, 30(8), $1-9$. 
Benavides, M., León, J., Veramendi, M. L., \& D’Azevedo, M. (2012). Los accidentes en los niños. Un estudio en contexto de pobreza. Lima, Peru: GRADE.

Bernacchi, E., \& Zelano, M. (2016). Multi-country study on the drivers of violence affecting children: Italian report. Florence, Italy: Istituto degli Innocenti.

Bourguignon, F. (1998). Crime as a social cost of poverty and inequality: A review focusing on developing countries. Paris, France: DELTA.

Bray, R., \& Dawes, A. (2016). Parenting, family care and adolescence in East and Southern Africa: An evidence-focused literature review (Innocenti Discussion Paper 2016-02). Florence, Italy: UNICEF Office of Research Innocenti.

Bronfenbrenner, U. (1979). The ecology of human development: Experiments by nature and design. Cambridge, MA: Harvard University Press.

Brown, S. (1995). Sexual coercion and reproductive health. New York, NY: Population Council.

Bryant, J. (2005). Children of international migrants in Indonesia, Thailand, and the Philippines: A review of evidence and policies (Innocenti Working Papers, no. 2005-05). Florence, Italy: UNICEF Office of Research - Innocenti.

Cavagnoud, R. (2011). Entre la escuela y la supervivencia: Trabajo adolescente y dinámicas familiares en Lima. Lima, Peru: Instituto de Estudios Peruanos, Instituto Francés de Estudios Andinos \& Fundación Telefónica.

Chiliya, N., Masocha, R., \& Zindiye, S. (2012). Challenges facing Zimbabwean cross border traders trading in South Africa: A review of literature. Chinese Business Review, 11(6), 564-570.

Christie, D. J. (2011). Peace psychology: Definitions, scope, and impact. The Encyclopedia of Peace Psychology. https://doi.org/10.1002/9780470672532.wbepp200

Christie, D. J. (2006). What is peace psychology the psychology of? Journal of Social Issues, 62(1), 1-17.

Christie, D. J., Wagner, R. V., \& Winter, D. A. (Eds.). (2001). Peace, conflict, and violence: Peace psychology for the 21st century. Englewood Cliffs, NJ: Prentice-Hall.

Capital Humano y Social (CHS) Alternativo. (2014). Explotación sexual de niños, niñas y adolescentes en la ciudad de Iquitos. Iquitos, Peru: CHS Alternativo \& Brot Fur die Welt.

Cuenca, R., \& Díaz, R. (2010). Ciudadanía de papel. La niñez indocumentada en el Perú. Lima, Peru: CIES \& Instituto de Estudios Peruanos.

Demurtas, P., Vitiello, M., Accorinti, M., Skoda, A., \& Perillo, C. (2018). In search of protection: Unaccompanied minors in Italy. New York, NY: Center for Migration Studies. Retrieved from http://cmsny.org/publications/2018smsc-cse-uam/.

Dube, R. (2013). She probably asked for it! A preliminary study into Zimbabwean societal perceptions of rape. Harare, Zimbabwe: Research and Advocacy Unit.

End Child Prostitution and Trafficking (ECPAT) Peru. (2005). ¿Mercancía sexual? Cómo hemos creado la demanda para la explotación sexual de niños, niñas y adolescentes en Perú. Lima, Peru: IDEIF, CODENI, REDES \& Movimiento El Pozo. Retrieved from http://www.chsalternativo.org/upload/archivos/archivo_112.pdf.

Espinoza Matos, M. J. (2000). Violencia en la familia en Lima y el Callao. Lima, Peru: Ediciones del Congreso del Perú.

Featherstone, B., Gupta, A., Morris, K. M., \& Warner, J. (2016). Let's stop feeding the risk monster: Towards a social model of 'child protection. Families, Relationships and Societies, 1(7), $7-22$.

Finkelhor, D., \& Jones, L. (2006). Why have child maltreatment and child victimization declined? Journal of Social Issues, 62(4), 685-716.

Fry, D., Hodzi, C., \& Nhenga, T. (2016). Addressing social norms that underpin violence against children in Zimbabwe: Findings and strategic planning document. Harare, Zimbabwe: Ministry of Public Services, Labour and Social Welfare.

Fulu, E., \& Miedema, S. (2015). Violence against women: Globalizing the integrated ecological model. Violence Against Women, 21(12), 1431-1455.

Galtung, J. (1985). Twenty-five years of peace research: Ten challenges and some responses. Journal of Peace Research, 22(2), 141-158. 
General Statistics of Vietnam (GSO). (2012). Exploratory research on trafficking in boys in Viet Nam. Hanoi, Vietnam: General Statistics of Vietnam.

Guedes, A., Bott, S., García-Moreno, C., \& Colombini, M. (2016). Bridging the gaps: A global review of intersections of violence against women and violence against children. Global Health Action, 9, 1-15.

Guerrero, G., \& Rojas, V. (2016). Understanding children's experiences of violence in Peru: Evidence from Young Lives (Innocenti Working Paper 2016-17). Florence, Italy: UNICEF Office of Research.

Heise, L. L. (1998). Violence against women: An integrated, ecological framework. Violence Against Women, 4(3), 262-290.

Hillis, S., Mercy, J., Amobi, A., \& Kress, H. (2016). Global prevalence of past-year violence against children: A systematic review and minimum estimates. Pediatrics, 137(3), e20154079.

Illanes, J. C. (2010). Migrant mothers and divided homes: Perceptions of immigrant Peruvian women about motherhood. Journal of Comparative Family Studies, 41(2), 205-224.

Instituto Nacional de Estadística e Informática (INEI). (2013). Encuesta Nacional de Relaciones Sociales ENARES. Lima, Peru: MIMP \& INEI.

Instituto Nacional de Estadística e Informática (INEI), \& International Organization for Migration (IOM). (2009). Migración Internacional en las familias peruanas y perfil del peruano retrornante. Lima, Peru: INEI.

International Organization for Migration, \& Movimiento El Pozo. (2005). Trata de mujeres para fines sexuales comerciales en el Perú. Lima, Peru: IOM \& Movimiento El Pozo.

International Programme on the Elimination of Child Labour (IPEC). (2007). Imperdonable. Estudio sobre la explotación sexual comercial de la infancia y adolescencia en Perú: Cajamarca, Cusco, Iquitos y Lima. Lima, Peru: Organización InternacionaI de Trabajo.

Jewkes, R. (2002). Intimate partner violence: Causes and prevention. The Lancet, 359(9315), $1423-1429$.

Jewkes, R., Nduna, M., Levin, J., Jama, N., Dunkle, K., Puren, A., \& Duvvury, N. (2008). Impact of stepping stones on incidence of HIV and HSV-2 and sexual behaviour in rural South Africa: Cluster randomised controlled trial. BMJ, 337, a506.

Jones, N., \& Villar, E. M. (2014). Is cash the answer? Lessons for child protection programming from Peru: The Juntos (Together) program has the potential to improve children's care and protection. Child Abuse \& Neglect, 38(3), 383-394.

Jones, N., Presler-Marshall, E., \& Thi Van Anh, T. (2014). Early marriage among Vietnam's H'mong. ODI country report. London, UK: Overseas Development Institute.

Kim, J. C., Watts, C. H., Hargreaves, J. R., Ndhlovu, L. X., Phetla, G., Morison, L. A., ... Pronyk, P. (2007). Understanding the impact of a microfinance-based intervention on women's empowerment and the reduction of intimate partner violence in South Africa. American Journal of Public Health, 97(10), 1794-1802.

Knerr, W., Gardner, F., \& Cluver, L. (2011). Preventing child abuse and interpersonal violence in low- and middle-income countries. SVRI Briefing Paper. SVRI, MRC \& Oak Foundation.

Know Violence in Childhood. (2017). Ending violence in childhood. Global report 2017. New Delhi, India: Know Violence in Childhood.

Krug, E. G., Dahlberg, L. L., Mercy, J. A., Zwi, A. B., \& Lozano, R. (2002). World report on violence and health. Geneva, Switzerland: World Health Organization.

Kumar, A. K., Sherr, L., Stern, V., \& Subrahmanian, R. (Eds.) (2017). Know violence in childhood: A global learning initiative. Psychology, Health \& Medicine, 22, 1-122. (Supp 1).

Le, M. T., Holton, S., Romero, L., \& Fisher, J. (2016). Polyvictimization among children and adolescents in low-and lower-middle-income countries: A systematic review and meta-analysis. Trauma, Violence, \& Abuse, 19(3), 323-342. https://doi.org/10.1177/1524838016659489

Leinaweaver, J. B. (2009). Los niños ayacuchanos. Una antropología de la adopción y la construcción familiar en el Perú. Lima, Peru: Instituto de Estudios Peruanos.

MacNair, R. M. (2015). Theories underlying research in peace psychology. In Methodologies in peace psychology (pp. 19-41). Cham, Switzerland: Springer. 
Magwa, S., \& Ingwani, V. (2014). Exploring sexual abuse of school children in families: A case study of Masvingo District, Zimbabwe. The International Journal of Humanities \& Social Studies, 2(9), 156-161.

Marcus, R. (2014). Poverty and violations of children's right to protection in low-and middleincome countries: A review of the evidence. London, UK: Overseas Development Initiative.

Maternowska, M. C., \& Fry, D. (2015). Understanding the drivers of violence. A step-by-step guide to conducting preliminary research around what drives violence. Florence, Italy: UNICEF Office of Research - Innocenti. Retrieved from https://www.unicef-irc.org/research/ pdf/440-TOOLKITstep-by-step_28Sept2016_OK.pdf

Maternowska, M. C., \& Potts, A. (2017). The Multi-Country Study on the Drivers of Violence Affecting Children: A child-centred integrated framework for violence prevention. Florence, Italy: UNICEF Office of Research - Innocenti. Retrieved from https://www.unicef-irc.org/ research/pdf/448-child-centered-brief.pdf

Maternowska, M. C., Potts, A., \& Fry, D. (2016). The multi-country study on the drivers of violence affecting children. A cross-country snapshot of findings. Florence, Italy: UNICEF Office of Research - Innocenti. Retrieved from www.unicef-irc.org/publications/874.

Maternowska, M. C., Fry, D., Potts, A., \& Casey, T. (2018). The multi-country study on the drivers of violence affecting children: Giving complexity clarity. Vulnerable Children \& Youth Studies, 13, 1-82. (Supp 1).

Ministerio de la Mujer y las Poblaciones Vulnerables (MIMP), \& UNICEF. (2016). The multicountry study on the drivers of violence affecting children: Country peport. Lima, Peru: Ministerio de la Mujer y las Poblaciones Vulnerables. Retrieved from https://www.mimp.gob. pe/direcciones/dgnna/contenidos/articulos.php?codigo $=6$

Morton, S., \& Casey, T. (2017). Changing national policy on violence affecting children: An impact assessment of UNICEF and partners' multi-country study on the drivers of violence affecting children in Peru. Edinburgh, Scotland: University of Edinburgh. Retrieved from https://www. era.lib.ed.ac.uk/handle/1842/22063.

Mujica, J. (2014). Elementos comparados del impacto de la trata de personas en la salud de víctimas adolescentes en el contexto de la minería ilegal de oro en Madre de Dios. Lima, Peru: PROMSEX \& ANESVAD.

Naschold, F. (2002). Why inequality matters for poverty (Inequality briefing no. 2). London, UK: Overseas Development Institute.

Nóblega, M. M. (2012). Risk and protective factors for physical and emotional intimate partner violence against women in a community of Lima, Peru. Journal of Interpersonal Violence, 27, 3644-3659.

Norman, R. E., Byambaa, M., De, R., Butchart, A., Scott, J., \& Vos, T. (2012). The long-term health consequences of child physical abuse, emotional abuse, and neglect: A systematic review and meta-analysis. PLoS Medicine, 9(11), e1001349.

Organisation for Economic Co-operation and Development (OECD). (2010). Peru. Atlas of gender and development: How social norms affect gender equality in non-OECD countries. Paris, France: OECD Publishing.

Parkes, J. (Ed.). (2015). Gender violence in poverty contexts: The educational challenge. New York: Routledge.

Pells, K., Ogando Portela, M. J., \& Espinoza, P. (2016). Experiences of peer bullying among adolescents and associated effects on young adult outcomes: Longitudinal evidence from Ethiopia, India, Peru and Viet Nam (Innocenti discussion paper). Florence, Italy: UNICEF Office of Research-Innocenti.

Pilisuk, M. (1998). The hidden structure of contemporary violence. Peace and Conflict, 4(3), 197-216.

Rumble, L., Ramly, A. A., Nuryana, M., \& Dunne, M. P. (2018). The importance of contextual factors in carrying out childhood violence surveys: A case study from Indonesia. Child Indicators Research, 11(2), 405-421. 
Rushing, R., Watts, C., \& Rushing, S. (2005). Living the reality of forced sex work: Perspectives from young migrant women sex workers in northern Vietnam. Journal of Midwifery \& Women's Health, 50(4), e41-e44.

Save the Children. (2008). Our broken dream: Child migration in Southern Africa. Johannesburg, South Africa: Save the Children UK.

Save the Children Norway Zimbabwe. (2010). An analysis of irregular child migration patterns: Beitbridge Child Reception Centre report. Harare, Zimbabwe: Save the Children.

Seedat, M., Van Niekerk, A., Suffla, S., \& Ratele, K. (2014). Psychological research and South Africa's violence prevention responses. South African Journal of Psychology, 44(2), 136-144.

Strocka, C. (2008). Unidos nos hacemos respetar. Jóvenes, identidades y violencia en Ayacucho. Lima, Peru: UNICEF/Instituto de Estudios Peruanos.

Torres-Zorrilla, J. (2010). Remesas en Ecuador y Perú. Lima, Peru: Centrum, Pontificia Universidad Católica del Perú.

UNICEF Viet Nam, UNICEF Office of Research - Innocenti, \& University of Edinburgh. (2017). Understanding the drivers of violence affecting children in Viet Nam. Hanoi, Viet Nam: UNICEF Viet Nam. Retrieved from: https://www.unicef-irc.org/files/upload/documents/ MCSDV_Viet\%20Nam_Understanding\%20Drivers\%20of\%20VAC.PDF

Vu Manh Loi. (2015). Data analysis of SAVY 1 and SAVY 2. UNICEF, Hanoi, Viet Nam.

Wagner, R. V. (1988). Distinguishing between positive and negative approaches to peace. Journal of Social Issues, 44(2), 1-15.

Wessells, M. G. (1999). Culture, power, and community: Intercultural approaches to psychosocial assistance and healing. In K. Nader, N. Dubrow, \& B. H. Stamm (Eds.), Honoring differences: Cultural issues in the treatment of trauma and loss (pp. 267-282). London, UK: Brunner/ Mazel.

World Health Organization (WHO), Centers for Disease Control and Prevention (CDC), Global Partnership to End Violence Against Children, Pan American Health Organization (PAHO), President's Emergency Plan for AIDS Relief (PEPFAR), ... \& the World Bank. (2016). INSPIRE: Seven strategies for ending violence against children. Geneva, Switzerland: WHO.

Yon Leau, C. J. (2013). Sexuality, social inequalities, and sexual vulnerability among low-income youth in the city of Ayacucho, Peru. Doctoral thesis, Department of Sociomedical Sciences. New York, NY: Columbia University.

Open Access This chapter is licensed under the terms of the Creative Commons Attribution 4.0 International License (http://creativecommons.org/licenses/by/4.0/), which permits use, sharing, adaptation, distribution and reproduction in any medium or format, as long as you give appropriate credit to the original author(s) and the source, provide a link to the Creative Commons license and indicate if changes were made.

The images or other third party material in this chapter are included in the chapter's Creative Commons license, unless indicated otherwise in a credit line to the material. If material is not included in the chapter's Creative Commons license and your intended use is not permitted by statutory regulation or exceeds the permitted use, you will need to obtain permission directly from the copyright holder.

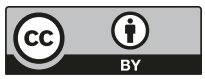

